\title{
地方都市圏における土地利用の規制格差と地域変容 一全国的な人口変動の動向と富山都市圏の事例分析一*
}

\section{Land Use Control Gaps between Municipalities of Local Conurbation Area and Regional Transformation -Trend of population change of Local Conurbation Area and Case Study of Toyama Conurbation Area -*}

片岸 将広**・川上光彦***・小柳 玩利****・埒 正浩*****

By Masahiro KATAGISHI** · Mitsuhiko KAWAKAMI*** • Takuto OYANAGI**** • Masahiro RACHI*****

\section{1. はじめに}

わが国は、第二次世界大戦後の復興にあわせて、急 激な人口増加と経済成長を遂げた。都市部への人口・都 市的土地利用の集積が進む中、無秩序な市街化を抑制す るための都市計画的対応として、1968年の新都市計画法 制定により区域区分（線引き）制度が導入された。

線引き制度は、計画的な市街化を図るための土地利 用コントロール手法として一定の効果を発揮してきた。 しかし、線引き都市計画区域では、市街化区域と市街化 調整区域との間に土地利用規制格差をもたらしているこ とに加え、地方部では車社会の進展等に伴う生活圈の広 域化やライフスタイルの変化等を背景に、都市的開発が 周辺の非線引き白地地域や都市計画区域外といった土地 利用規制の緩い地域（当初は都市的開発が生じないと想 定していた地域）に及んでおり、線引き都市計画区域内 に留まらず、非線引き都市計画区域や都市計画区域外と の間にも新たな土地利用規制格差を生じている。さらに、 市町村合併により一つの自治体内に線引き・非線引きの 都市計画区域が混在する状況が生じており、都市計画区 域の再編や土地利用規制格差の是正に関する議論が各地 で行われている。なお、線引き・非線引きの土地利用規 制格差の問題については、これまでにいくつかの研究等 で指摘されており、その是正に向けた都市計画的対応と して、開発許可条例 ${ }^{1)}$ や特定用途制限地域2) ${ }^{23)}$ 、市街化調 整区域における地区計画”などの適用事例がみられる。

一方、わが国ではすでに人口減少時代を迎えている。 2005年国勢調査結果では、2000年から2005年にかけて、 すでに32道県で人口が減少しており、三大都市圈に比心゙ て地方都市圈での人口減少が先行して進んでいる。さら に、国立社会保障・人口問題研究所可によると、人口が 減少する都道府県は今後も増加を続け、2010年から 2015 年にかけては42道府県、2020年から2025年にかけては沖

*キーワーズ : 都市圏、土地利用規制格差、人口変動

**正員、(株日本海コンサルタント計画技術研究室

（干921-8042 石川県金沢市泉本町2丁目126番地、

TEL:076-243-8291、FAX:076-243-0810)

***正員、工博、金沢大学理工研究域環境デザイン学系

****学生員、金沢大学工学部土木建設工学科

*****正員、博（工）、(株日本海コンサルタント計画本部
縄県を除く46都道府県、2025年以降はすべての都道府県 で人口が減少することが予想されている。

このことから、成長・拡大を前提とした線引き制度 をはじめとする都市計画制度は大きな転換期を迎えてい る。社会資本整備審議会都市計画・歴史的風土分科会都 市計画部会が平成21年6月に発表した「都市政策の基本 的な課題と方向検討小委員会報告」では、都市の将来ビ ジョンに関する共通の指針として「エコ・コンパクトシ ティの実現」等を掲げ、これまでの拡散型都市構造から 集約型・低炭素型の都市構造を目指寸方向が示されてい る。また、都市計画制度見直しの方向性として、「長期 安定的な土地利用計画システムの確立」などが示されて いる。これらを具体化していくためには、これまでの都 市計画制度に基づく土地利用規制格差が地域変容に与え てきた影響について、都市圈レベルで分析・考察する必 要がある。そこで、本論文では、地方都市圈を対象に、 土地利用規制格差と人口変動等の関係を明らかにし、広 域的な土地利用コントロールの課題について考察するこ とを目的とする。

\section{2. 既存研究の整理}

都市圈レベルの地域変容について、内田ら ${ }^{6)}$ は、県庁 所在地方都市圈（32都市圈）を対象に、人口変動や通勤 者数の変化等から、市街地拡大の実態を明らかにすると ともに、新潟都市圈における事例分析を通じて、モータ リゼーションの進展や未線引き白地（緩規制地域）の存 在に対応した区域区分制度の運用の必要性を述べている。 この他、都市計画区域やその土地利用規制格差に着目し た研究として、線引き廃止後の開発動向等の変化を扱っ た研究 $\left.{ }^{77}, 8\right), 99$ や、市町村合併後の異なる複数の都市計画 区域の混在による地域格差や都市計画区域再編等を扱っ た研究10,111,12) などがみられる。しかし、全国の地方都 市圈を対象として、現行の都市計画制度下における土地 利用規制格差と人口変動の関係をマク口的に分析した研 究は少ない。また、地方都市圈における人口減少時代の 都市計画制度を検討していくためには、土地利用規制格 差と地域変容 (人口変動や開発動向、地価との関係等) の関係について事例分析を積み重致、広域的な視点から 土地利用制度のあり方を模索していく必要があると考え られる。 


\section{3. 研究の方法}

本研究では、地方都市圈を「地方圈 ${ }^{(1)}$ における2000年 時点の県庁所在都市及び中核市（計42市）を中心都市と する都市圈」と定義する。なお、都市圈の設定にあたつ ては、都市雇用圈 ${ }^{13)}$ の考え方を適用寸る ${ }^{(2)}$ とともに、第 1 回線引きが概ね完了したと考えられる1975年時点の都 市圈を設定し、それらの構成市町村（中心都市を含む 468市町村）の人口変動等について分析・考察する。

\section{（1）地方都市圏の人口変動に関する考察}

まず、地方都市圈を構成する市町村について、その位 置関係を「中心都市 (42市) ・ 隣接都市（中心都市に接 する市町村 : 260 市町村）・連接都市（中心都市に接さ ず隣接都市に接する市町村：166市町村）」の3つに区 分し、線引きの状況を踏まえつつ、都市圈全体の人口変 動について考察する。なお、都市圈を構成する都市計画 区域の人口や面積については、都市計画年報（各年3月 末現在、監修: 国土交通省・発行 : 財団法人都市計画協 会）のデータを用いる。なお、全国的な分析においては、 区域区分別の人口規模が把握可能であり、市町村合併の 影響を受けない1980年〜2000年の20年間のデータを用い ることとする。

\section{（2）富山都市圏における事例分析}

上記の全国的な分析結果の中でも典型的な区域区分設 定タイプ (中心都市 : 線引き、隣接都市 : 線引き十非線 引き、連接都市 : 非線引き) であり、全国に先駆けて公 共交通を軸としたコンパクトな都市づくりを進めている 富山市を中心とした富山都市圈を事例とし、都市計画基 礎調查 ${ }^{(3)}$ のデータなどをもとに、土地利用規制格差と 地域変容 (人口変動や開発動向、地価との関係等)につ いて分析・考察する。なお、富山都市圈の事例分析にお いては、市町村合併直前までの動向を把握するため、 1985年〜2005年の 20 年間のデータを用いることとする。 上記の全国的分析の対象年次と 5 年間のズレがあるもの の、20年間にわたる長期的な変動に大きな差異はない。

\section{4. 地方都市圏の人口変動に関する考察}

\section{（1）都市計画区域数と区域区分指定状況の推移}

全国の都市計画区域数及び区域区分設定区域数の推 移を表-1に示す。2008年都市計画現況調査結果（国土交 通省）によると、2008年3月31日現在で1, 231の都市計画 区域が存在し、そのうち線引き導入区域は282 区域 (23\%) であり、約 8割の都市計画区域は非線引きとな っている。また、2000年都市計画年報から1975年〜2000 年の 25 年間における区域区分設定状況の推移をあわせて みると、制度創設当初から人口増加が著しかった時期に あたる1960年〜1980年代には増加傾向にあったものの、 人口増加・経済成長が落ち着いた1990年代以降の設定区 域数はほぼ横ばいとなり、2000年〜2008年には全国的な
市町村合併や線引き廃止の流れを受け、都市計画区域・ 区域区分ともに設定区域数が減少している。

\section{表-1 都市計画区域数 - 区域区分設定区域数の推移}

\begin{tabular}{|c|c|c|c|c|c|c|c|}
\hline & \begin{tabular}{|l} 
都市計画 \\
区域数
\end{tabular} & \begin{tabular}{|c|} 
区域区分 \\
設定区域 \\
数
\end{tabular} & $\begin{array}{c}\text { 区域区分 } \\
\text { 非設定区 } \\
\text { 域数 }\end{array}$ & \begin{tabular}{|l|}
1975 年を \\
1.0 とした \\
区域区分 \\
設定区域 \\
増減率 \\
\end{tabular} & \begin{tabular}{|l||}
1975 年を \\
1.0 とした \\
区域区分 \\
非設定区 \\
域増減率
\end{tabular} & \begin{tabular}{|c} 
区域区分 \\
設定区域 \\
割合
\end{tabular} & $\begin{array}{c}\text { 区域区分 } \\
\text { 非設定区 } \\
\text { 域割合 }\end{array}$ \\
\hline 1975年 & 1,145 & 298 & 847 & 1.000 & 1.000 & $26.0 \%$ & 74.0\% \\
\hline 1980年 & 1,179 & 315 & 864 & 1.057 & 1.020 & $26.7 \%$ & $73.3 \%$ \\
\hline 1985年 & 1,212 & 325 & 887 & 1.091 & 1.047 & $26.8 \%$ & $73.2 \%$ \\
\hline 1990年 & 1,243 & 329 & 914 & 1.104 & 1.079 & $26.5 \%$ & $73.5 \%$ \\
\hline 1995年 & 1,281 & 336 & 945 & 1.128 & 1.116 & $26.2 \%$ & $73.8 \%$ \\
\hline 2000年 & 1,308 & 337 & 971 & 1.131 & 1.146 & $25.8 \%$ & $74.2 \%$ \\
\hline 2008年 & 1,231 & 282 & 949 & 0.946 & 1.120 & $22.9 \%$ & $77.1 \%$ \\
\hline
\end{tabular}

\section{（2）地方都市圏の人口変動}

前述の都市圈設定に基づき、42都市圈468市町村を対 象に、中心・隣接・連接の都市区分と線引きの有無の関 係を踏まえた人口変動を表-2〜表-5に示す。

\section{表-2 地方都市圏（全体）の人口変動}

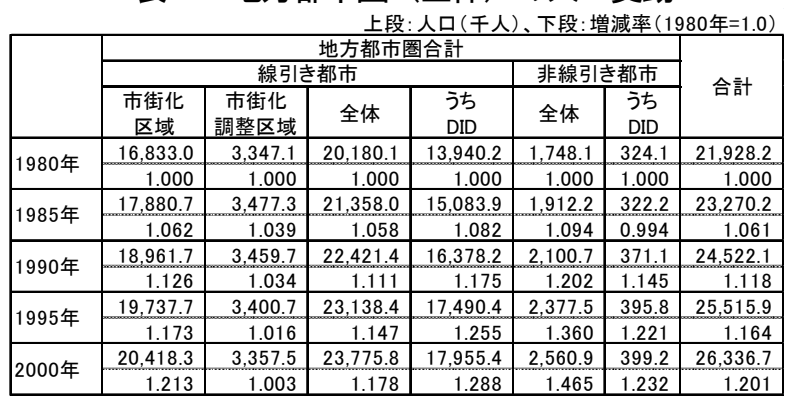

\section{表-3 地方都市圏（中心都市）の人口変動}

\begin{tabular}{|c|c|c|c|c|c|c|c|}
\hline & \multicolumn{6}{|c|}{ 中心都市 } & \multirow{3}{*}{ 合計 } \\
\hline & \multicolumn{4}{|c|}{ 線引き都市 } & \multicolumn{2}{|c|}{ 非線引き都市 } & \\
\hline & $\begin{array}{c}\text { 市街化 } \\
\text { 区域 }\end{array}$ & $\begin{array}{c}\text { 市街化 } \\
\text { 調整区域 }\end{array}$ & 全体 & $\begin{array}{l}j \hbar \\
\text { DID }\end{array}$ & 全体 & $\begin{array}{l}j \hbar \\
\text { DID }\end{array}$ & \\
\hline \multirow{2}{*}{ 1980年 } & $13,658.8$ & $1,930.0$ & $15,588.8$ & $12,016.7$ & 117.0 & 44.2 & $15,705.8$ \\
\hline & 1.000 & 1.000 & 1.000 & 1.000 & 1.000 & 1.000 & 1.000 \\
\hline \multirow{2}{*}{ 1985年 } & 14.448 .0 & $1,967.1$ & $16,415.1$ & 12.917 .1 & 121.0 & 44.5 & 16.536 .1 \\
\hline & 1.058 & 1.019 & 1.053 & 1.075 & 1.034 & 1.007 & 1.053 \\
\hline \multirow{2}{*}{ 1990年 } & $15,345.8$ & $1,947.3$ & $17,293.1$ & $13,978.4$ & 127.3 & 65.2 & $17,420.4$ \\
\hline & 1.124 & 1.009 & 1.109 & 1.163 & 1.088 & 1.476 & 1.109 \\
\hline \multirow{2}{*}{ 1995年 } & $15,846.5$ & $1,932.1$ & $17,778.6$ & $14,665.6$ & 133.9 & 68.4 & 17.912 .5 \\
\hline & 1.160 & 1.001 & 1.140 & 1.220 & 1.144 & 1.548 & 1.141 \\
\hline \multirow{2}{*}{ 2000年 } & $16,256.3$ & $1,900.2$ & $18,156.5$ & $15,026.6$ & 140.7 & 74.0 & $18,297.2$ \\
\hline & 1.190 & 0.985 & 1.165 & 1.250 & 1.203 & 1.676 & 1.165 \\
\hline
\end{tabular}

表-4 地方都市圏 (隣接都市) の人口変動

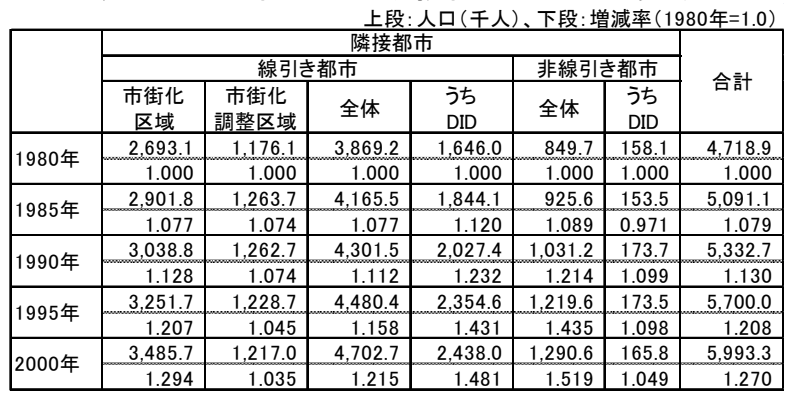

表-5 地方都市圏 (連接都市) の人口変動

上段: 人口(千人)、下段: 增減率 (1980年 $=1.0)$

\begin{tabular}{|c|c|c|c|c|c|c|c|}
\hline & \multicolumn{6}{|c|}{ 連接都市 } & \multirow{3}{*}{ 合計 } \\
\hline & \multicolumn{4}{|c|}{ 線引き都市 } & \multicolumn{2}{|c|}{ 非線引き都市 } & \\
\hline & $\begin{array}{c}\text { 市街化 } \\
\text { 区域 }\end{array}$ & $\begin{array}{c}\text { 市街化 } \\
\text { 調整区域 }\end{array}$ & 全体 & $\begin{array}{l}\text { jち } \\
\text { DID }\end{array}$ & 全体 & $\begin{array}{l}\text { jち } \\
\text { DID }\end{array}$ & \\
\hline \multirow{2}{*}{ 1980年 } & 481.1 & 241.0 & 722.1 & 277.5 & 781.4 & 121.9 & 1.503 .5 \\
\hline & 1.000 & 1.000 & 1.000 & 1.000 & 1.000 & 1.000 & 1.000 \\
\hline \multirow{2}{*}{ 1985年 } & 530.9 & 246.5 & 777.4 & 322.7 & 865.6 & 124.3 & $1,643.0$ \\
\hline & 1.104 & 1.023 & 1.077 & 1.163 & 1.108 & 1.020 & 1.093 \\
\hline \multirow{2}{*}{ 1990年 } & 577.1 & 249.7 & 826.8 & 372.4 & 942.2 & 132.2 & $1,769.0$ \\
\hline & 1.200 & 1.036 & 1.145 & 1.342 & 1.206 & 1.085 & 1.177 \\
\hline \multirow{2}{*}{ 1995年 } & 639.5 & 239.9 & 879.4 & 470.1 & $1,024.0$ & 153.9 & $1,903.4$ \\
\hline & 1.329 & 0.995 & 1.218 & 1.694 & 1.310 & 1.263 & 1.266 \\
\hline \multirow{2}{*}{ 2000年 } & 676.3 & 240.3 & 916.6 & 490.7 & 1.129 .6 & 159.4 & $2,046.2$ \\
\hline & 1.406 & 0.997 & 1.269 & 1.768 & 1.446 & 1.308 & 1.361 \\
\hline
\end{tabular}


まず、1980年を1.0とした地方都市圈全体の人口変動 をみると（表-2）、1980年～2000年の20年間で1. 201ま で増加している。線引きの有無との関係をみると、2000 年時点で地方都市圈 26,336 千人のうち 20,418 千人

（78\%）が市街化区域に居住しており、そのうちの 17, 955千人（88\%）がD I D内居住者となっている。ま た、中心・隣接・連接のいずれの都市においても市街化 区域やD I Dの人口増加率が高くなっている。これらの ことから、線引き制度のもと、計画的に市街化を図る心゙ き区域での人口集積が進んできたことがわかる。

一方、同期間の都市計画ゾーニングと人口増減率の 関係をみると、全体では市街化区域で1.213に増加、市 街化調整区域では1.003とほぼ変化していないのに対し、 非線引き都市では1. 465 と相対的に大きな増加率を示し ている。これについて、都市圈内の位置関係をあわせて みると、隣接都市の非線引き区域で1. 519、連接都市の 非線引き区域で1.446といずれも高い増加率を示してお り、規制の緩い周辺市町村での人口増加が進んできてい る実態がうかがえる。

\section{（3）地方都市圏の区域区分指定状況とタイプ分類}

地方都市圏における1980年時点の線引き状況をみると （表-6）、線引き都市のみで都市圈を構成しているもの

(Type1）が10都市圈（24\%）であるのに対し、中心都 市が線引き都市で隣接・連接に非線引き都市含む都市圈 （Type2）が31都市圏（74\%）を占めており、非線引き 都市のみで都市圈を構成しているもの（Type3）は山口 都市圏のみとなっている。

上記 3 タイプのそれぞれの人口変動を表-7に示す。ま ず、線引き都市のみで都市圈を構成するType1について、
表-6 地方都市圏の線引き状況

\begin{tabular}{|c|c|c|c|c|c|c|c|}
\hline \multirow{2}{*}{ タイプ } & \multirow{2}{*}{ 都市圏 } & \multicolumn{2}{|c|}{ 中心 } & \multicolumn{2}{|c|}{ 隣接 } & \multicolumn{2}{|c|}{ 連接 } \\
\hline & & 線 & 非 & 線 & 非 & 線 & 非 \\
\hline \multirow{10}{*}{$\begin{array}{c}\text { 【Type1】 } \\
\text { 線引きのみ }\end{array}$} & 旭川 & 0 & & 0 & & & \\
\hline & 青森 & 0 & & 0 & & & \\
\hline & 山形 & 0 & & 0 & & & \\
\hline & 大津 & 0 & & 0 & & & \\
\hline & 静岡 & 0 & & 0 & & & \\
\hline & 福山 & 0 & & 0 & & & \\
\hline & 福島 & 0 & & 0 & & 0 & \\
\hline & いわき & 0 & & & & & \\
\hline & 松山 & 0 & & 0 & & 0 & \\
\hline & \begin{tabular}{|l} 
那覇 \\
\end{tabular} & 0 & & 0 & & 0 & \\
\hline \multirow{31}{*}{$\begin{array}{c}\text { 【Type2】 } \\
\text { 線引き+非線引き }\end{array}$} & 秋田 & 0 & & 0 & 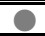 & 0 & 0 \\
\hline & 新潟 & 0 & & 0 & 8 & 0 & 0 \\
\hline & 甲府 & 0 & & 0 & 0 & 0 & 0 \\
\hline & 高知 & 0 & & 0 & 0 & 0 & 0 \\
\hline & 福岡 & 0 & & 0 & 0 & 0 & 0 \\
\hline & 熊本 & 0 & & 0 & 0 & 0 & 0 \\
\hline & 岐阜 & 0 & & 0 & 0 & 0 & \\
\hline & 德島 & 0 & & 0 & 0 & 0 & \\
\hline & 仙台 & 0 & & 0 & 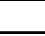 & 0 & 0 \\
\hline & 広島 & 0 & & 0 & & 0 & 0 \\
\hline & 浜松 & 0 & & 0 & & 0 & 0 \\
\hline & 水戸 & 0 & & 0 & & 0 & 0 \\
\hline & 金沢 & 0 & & 0 & 0 & & 0 \\
\hline & 福井 & 0 & & 0 & 0 & & 0 \\
\hline & 長野 & 0 & & 0 & 0 & & 0 \\
\hline & 和歌山 & 0 & & 0 & 0 & & 0 \\
\hline & 鳥取 & 0 & & 0 & 0 & & 0 \\
\hline & 松江 & 0 & & O & 0 & & 0 \\
\hline & \begin{tabular}{|l|} 
佐賀 \\
\end{tabular} & 0 & & 0 & 0 & & 0 \\
\hline & 宮崎 & 0 & & 0 & 0 & & 0 \\
\hline & 前橋 & 0 & & 0 & 0 & & 0 \\
\hline & 宇都宮 & 0 & & 0 & & & 0 \\
\hline & 岡山 & 0 & & 0 & & & 0 \\
\hline & 高松 & 0 & & 은 & & & 0 \\
\hline & 長崎 & 0 & & 0 & & & 0 \\
\hline & 札幌 & 0 & & 은 & 은 & & \\
\hline & 富山 & 0 & & 0 & 0 & & \\
\hline & 盛岡 & 0 & & 0 & 0 & & \\
\hline & 大分 & 0 & & 은 & 은 & & \\
\hline & 郡山 & 0 & & & 웅 & & \\
\hline & 鹿児島 & 0 & & & 0 & & 0 \\
\hline $\begin{array}{c}\text { 【Type3】 } \\
\text { 非線引きのみ }\end{array}$ & |山口 & & 0 & & - & & \\
\hline
\end{tabular}

表-7＼cjkstart地方都市圏における線引きタイプ別の人口変動

\begin{tabular}{|c|c|c|c|c|c|c|c|c|c|c|c|c|c|c|}
\hline \multirow[b]{2}{*}{ タイプ } & \multirow[b]{2}{*}{ 年代 } & \multicolumn{4}{|c|}{ 中心都市 } & \multicolumn{4}{|c|}{ 隣接都市 } & \multicolumn{4}{|c|}{ 連接都市 } & \multirow[b]{2}{*}{ 総計 } \\
\hline & & $\begin{array}{c}\text { 市街化 } \\
\text { 区域 } \\
\end{array}$ & $\begin{array}{l}\text { 調整 } \\
\text { 区域 } \\
\end{array}$ & $\begin{array}{l}\text { 非線 } \\
\text { 引き } \\
\end{array}$ & 計 & $\begin{array}{c}\text { 市街化 } \\
\text { 区域 } \\
\end{array}$ & $\begin{array}{l}\text { 調整 } \\
\text { 区域 } \\
\end{array}$ & $\begin{array}{l}\text { 非線 } \\
\text { 引き } \\
\end{array}$ & 計 & $\begin{array}{c}\text { 市街化 } \\
\text { 区域 } \\
\end{array}$ & $\begin{array}{l}\text { 調整 } \\
\text { 区域 } \\
\end{array}$ & $\begin{array}{l}\text { 非線 } \\
\text { 引き }\end{array}$ & 計 & \\
\hline \multirow{10}{*}{$\begin{array}{c}\text { 【Type 1】 } \\
\text { 線引き } \\
\text { のみ }\end{array}$} & \multirow{2}{*}{ 1980年 } & $\begin{array}{l}2,599.4 \\
\end{array}$ & 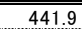 & & \begin{tabular}{|c|}
$3,066.2$ \\
\end{tabular} & (472.0 & 266.7 & & \begin{tabular}{|l|l|}
738.4 \\
\end{tabular} & \begin{tabular}{ll|}
125.8 \\
\end{tabular} & 80.9 & & 206.7 & $\begin{array}{l}4,011.3 \\
\end{array}$ \\
\hline & & 1.000 & 1.000 & & 1.000 & 1.000 & 1.000 & & 1.000 & 1.000 & 1.000 & & 1.000 & 1.000 \\
\hline & \multirow{2}{*}{ 1985年 } & $2,782.4$ & 423.4 & & $3,206.0$ & 517.4 & 278.7 & 13.5 & 809.5 & 143.4 & 82.3 & & 225.7 & $4,241.2$ \\
\hline & & 1.070 & 0.958 & & 1.046 & 1.096 & 1.045 & 1.000 & 1.096 & 1.140 & 1.017 & & 1.092 & 1.057 \\
\hline & \multirow{2}{*}{ 1990年 } & 2.864 .8 & 425.1 & & $3,291.8$ & 551.0 & 287.2 & 13.5 & 856.5 & 161.6 & 82.6 & & 244.4 & 4.392 .7 \\
\hline & & 1.102 & 0.962 & & 1.074 & 1.167 & 1.077 & 1.000 & 1.160 & 1.285 & 1.021 & & 1.182 & 1.095 \\
\hline & \multirow{2}{*}{ 1995年 } & $2,933.0$ & 421.4 & & $3,366.3$ & 597.5 & 281.9 & 26.0 & 911.1 & 180.1 & 82.9 & & 263.8 & $4,541.2$ \\
\hline & & 1.128 & 0.954 & & 1.098 & 1.266 & 1.057 & 1.926 & 1.234 & 1.432 & 1.025 & & 1.276 & 1.132 \\
\hline & \multirow{2}{*}{ 2000年 } & $2,988.0$ & 414.5 & & 3.402 .5 & 633.7 & 287.9 & 25.9 & 947.8 & 188.1 & 87.3 & & 275.4 & $4,625.7$ \\
\hline & & 1.149 & 0.938 & & 1.110 & 1.343 & 1.079 & 1.919 & 1.284 & 1.495 & 1.079 & & 1.332 & 1.153 \\
\hline \multirow{10}{*}{$\begin{array}{l}\text { 【Type2】 } \\
\text { 線引き+ } \\
\text { 線引き }\end{array}$} & \multirow{2}{*}{ 1980年 } & 11.059 .4 & $1,488.1$ & 6.5 & \begin{tabular}{|l||}
$12,564.1$ \\
\end{tabular} & $2,221.1$ & 909.4 & 831.5 & $4,009.8$ & 355.3 & 160.1 & 781.4 & $1,296.9$ & $17,870.8$ \\
\hline & & 1.000 & 1.000 & 1.000 & 1.000 & 1.000 & 1.000 & 1.000 & 1.000 & 1.000 & 1.000 & 1.000 & 1.000 & 1.000 \\
\hline & \multirow{2}{*}{ 1985年 } & $\begin{array}{r}11,665.6 \\
\end{array}$ & 1.543 .7 & 6.4 & $13,219.5$ & $2,384.4$ & 985.0 & 892.6 & 4.255 .7 & 387.5 & 164.2 & 865.6 & 1.422 .2 & 18.897 .4 \\
\hline & & 1.055 & 1.037 & 0.985 & 1.052 & 1.074 & 1.083 & 1.073 & 1.061 & 1.091 & 1.026 & 1.108 & 1.097 & 1.057 \\
\hline & \multirow{2}{*}{ 1990年 } & $12,481.0$ & $\begin{array}{r}1.522 .2 \\
.1 .92\end{array}$ & 6.4 & $14,008.8$ & $2,487.8$ & 975.5 & 996.7 & 4.433 .4 & 415.5 & 167.1 & 942.2 & 1.525 .3 & $19,967.5$ \\
\hline & & 1.129 & 1.023 & 0.985 & 1.115 & 1.120 & 1.073 & 1.199 & 1.106 & 1.169 & 1.044 & 1.206 & 1.176 & 1.117 \\
\hline & \multirow{2}{*}{ 1995年 } & $12,913.5$ & $1,510.7$ & 7.2 & $14,423.6$ & $2,654.2$ & 946.8 & 1.171 .5 & 4.800 .4 & 459.4 & 157.0 & 1.024 .0 & 1.640 .5 & $20,864.5$ \\
\hline & & 1.168 & 1.015 & 1.108 & 1.148 & 1.195 & 1.041 & 1.409 & 1.197 & 1.293 & 0.981 & 1.310 & 1.265 & 1.168 \\
\hline & \multirow{2}{*}{ 2000年 } & $13,268.3$ & 1.485 .7 & 7.2 & $14,768.3$ & $2,852.0$ & 929.1 & $1,242.3$ & $5,047.6$ & 488.2 & 153.0 & $1,129.6$ & $1,795.4$ & $21,611.3$ \\
\hline & & 1.200 & 0.998 & 1.108 & 1.175 & 1.284 & 1.022 & 1.494 & 1.259 & 1.374 & 0.956 & 1.446 & 1.384 & 1.209 \\
\hline \multirow{10}{*}{$\begin{array}{c}\text { 【Type3】 } \\
\text { 非線引き } \\
\text { のみ }\end{array}$} & \multirow{2}{*}{ 1980年 } & & & 110.5 & 110.5 & & & 18.2 & 18.2 & & & & & 128.7 \\
\hline & & & & 1.000 & 1.000 & & & 1.000 & 1.000 & & & & & 1.000 \\
\hline & \multirow{2}{*}{ 1985年 } & & & 114.6 & 114.6 & & & 19.5 & 19.5 & 5 & & & & 134.1 \\
\hline & & & & 1.037 & 1.037 & & & 1.071 & 1.071 & & & & & 1.042 \\
\hline & \multirow{2}{*}{ 1990年 } & & & 120.9 & 120.9 & & 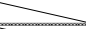 & 21.0 & 21.0 & 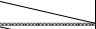 & & & & 141.9 \\
\hline & & & & 1.094 & 1.094 & & & 1.154 & 1.154 & & & & & 1.103 \\
\hline & \multirow{2}{*}{ 1995年 } & & & 126.7 & 126.7 & & & 22.1 & 22.1 & 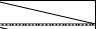 & & & & 148.8 \\
\hline & & & & 1.147 & 1.147 & & & 1.214 & 1.214 & & & & & 1.156 \\
\hline & \multirow{2}{*}{ 2000年 } & 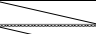 & & 133.5 & 133.5 & & & 22.4 & 22.4 & & & & & 155.9 \\
\hline & & & & 1.208 & 1.208 & & & 1.231 & 1.231 & & & & & 1.211 \\
\hline
\end{tabular}


1980年を1.0とした人口増減率をみると、市街化区域で の人口増加率が相対的に高く、2000年時点の増加率は隣 接都市で1. 343、連接都市で1. 495 となっている。これら はType2の隣接・連接の市街化区域の増加率に比べても 高い值となっている一方、市街化調整区域での大きな人 口変動はみられないことから、非線引き都市を含む都市 圏よりも市街化区域への人口集積が進んでいるといえる。 ただし、Type1については、1980年以降に都市計画区域 外の一部が非線引き都市計画区域に指定されたエリアに おいて急激な人口増加がみられ、規制の緩い地域への住 宅開発等の滲夕出しが生じているものと考えられる。

次に、隣接都市あるいは連接都市において、線引き 都市と非線引き都市が混在しているType 2 の口変動を みると、2000年時点の人口増加率は隣接都市の非線引き 区域で1. 494、連接都市の非線引き区域で1.446となって おり、市街化区域（中心：1.200、隣接：1.284、連接 : 1. 374）よりも高い伸び率を示している。線引き制度の 一定の効果により市街化区域が受け持つ人口が圧倒的に 多いものの、モータリゼーションの進展等にあわせてス プロール化が進行し、規制の厳しい市街化調整区域を飛 び越えて、隣接都市あるいは連接都市の非線引き区域で 都市的土地利用が進んでおり、これらは地方都市圈の典 型的な変化であると考えられる。

中心都市と隣接都市がいずれも非線引きであるType3 について、2000年時点の中心都市の非線引き区域の人口 増加率は1.208、隣接都市の非線引き区域で1.231 となっ ており、5年ごとの増加率は隣接都市の方が若干大きく なっている。これらの変化については、より詳細な分析 が必要であるが、中心都市が非線引きである都市圏でも、 隣接都市を含む広域的な人口変動が進んでいる。

以上のことから、地方都市圈では、中心都市のみ線 引きで、隣接・連接に非線引き都市を含む都市圈が多数 であり、線引き都市の市街化区域内における人口増加に 加えて、土地利用規制の緩い（当初は都市的な開発を想 定していなかった）非線引きの周辺都市に開発・人口増 加が及んでいる実態が明らかとなった。

\section{5. 富山都市圏における事例分析}

\section{（1）富山都市圏の土地利用規制格差と地域変容}

富山都市圏（困-1）における都市計画区分と人口変動 の関係をみると（表-8）、1985年を1.0とした場合、 2005年時点の市街化区域では1.056、市街化調整区域で は1.019、非線引き用途地域では0.946となっている一方、 非線引き白地地域では1. 260 となっており、人口増加率 が相対的に高い。なお、都市計画区域外の人口は減少が 続いており、2005年時点で0.659まで減少している。

これらの人口変動を踏まえ、2002年〜2006年の5年間 における用途別農地転用面積の合計值をみると（表-9）、

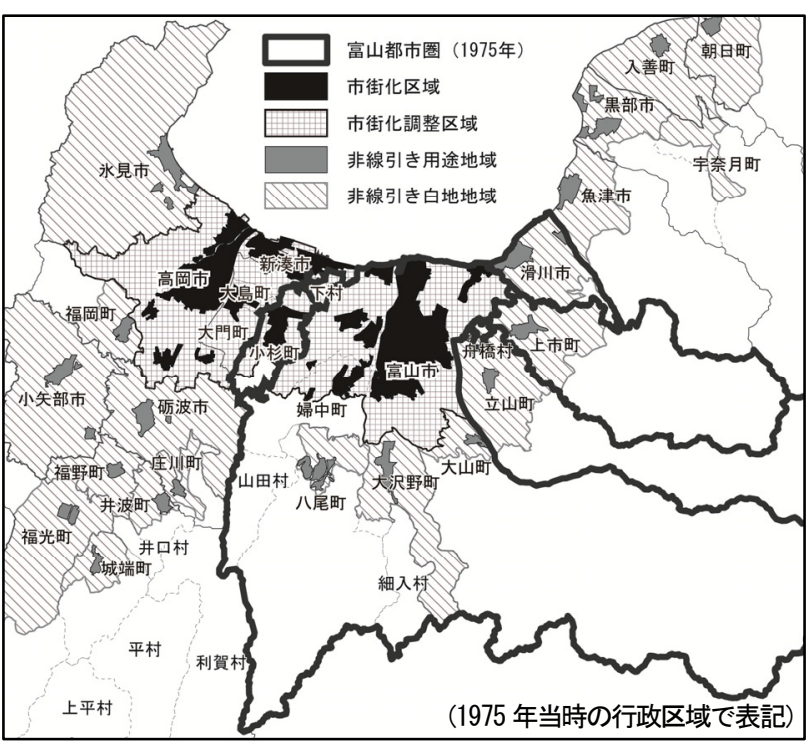

図-1 富山都市圏と県内の都市計画区域

表-8 富山都市圏の人口変動

\begin{tabular}{|c|c|c|c|c|c|}
\hline & & 段: 人口( & 人)、下段 & 畺減率 (1) & 35 年=1.0) \\
\hline & 1985年 & 1990年 & 1995年 & 2000年 & 2005年 \\
\hline \multirow{2}{*}{ 市街化区域 } & 313,841 & 323,753 & 331,018 & 335,609 & 331,281 \\
\hline & 1.000 & 1.032 & 1.055 & 1.069 & 1.056 \\
\hline \multirow{2}{*}{ 市街化調整区域 } & 110,074 & 106,565 & 107,466 & 105.501 & 112,137 \\
\hline & 1.000 & 0.968 & 0.976 & 0.958 & 1.019 \\
\hline \multirow{2}{*}{ 非線引き用途地域 } & 51,108 & 51,755 & 50,048 & 48,652 & 48,351 \\
\hline & 1.000 & 1.013 & 0.979 & 0.952 & 0.946 \\
\hline \multirow{2}{*}{ 非線引き白地地域 } & 70,286 & 70,612 & 81,655 & 87,153 & 88,543 \\
\hline & 1.000 & 1.005 & 1.162 & 1.240 & 1.260 \\
\hline \multirow{2}{*}{ 都市計画区域外 } & 29,164 & 27,659 & 20,644 & 20,305 & 19,214 \\
\hline & 1.000 & 0.948 & 0.708 & 0.696 & 0.659 \\
\hline \multirow{2}{*}{ 合計 } & 574,473 & 580,344 & 590,831 & 597,220 & 599,526 \\
\hline & 1.000 & 1.010 & 1.028 & 1.040 & 1.044 \\
\hline
\end{tabular}

表-9＼cjkstart富山都市圏の用途別農地転用面積（2002～2006 年）

\begin{tabular}{|l|r|r|r|r|r|}
\hline & \multicolumn{1}{|c|}{ 住宅 } & \multicolumn{1}{c|}{ 工業 } & \multicolumn{1}{c|}{ 公共 } & \multicolumn{1}{c|}{ その他 } & \multicolumn{1}{c|}{ 合計 } \\
\hline 市街化区域 & 125.87 & 21.59 & 0.66 & 50.48 & 198.59 \\
\hline 市街化調整区域 & 24.84 & 7.08 & 3.58 & 66.82 & 102.32 \\
\hline 非線引き用途地域 & 10.58 & 0.55 & 0.68 & 7.82 & 19.63 \\
\hline 非線引き白地地域 & 40.62 & 16.69 & 4.49 & 55.40 & 117.21 \\
\hline 都市計画区域外 & 2.76 & 1.38 & 0.48 & 30.86 & 35.49 \\
\hline 合計 & 204.67 & 47.31 & 9.88 & 211.38 & 473.24 \\
\hline
\end{tabular}
資料 : 2007 年都市計画基礎調査 (富山県)

\section{表-10 富山都市圏の用途別新築件数（2002 2006 年）}

\begin{tabular}{|l|r|r|r|r|r|}
\hline & \multicolumn{1}{|c|}{ 住宅 } & \multicolumn{1}{c|}{ 商業 } & \multicolumn{1}{c|}{ 工業 } & \multicolumn{1}{c|}{ その位: 件 } & \multicolumn{1}{c|}{ 合計 } \\
\hline 市街化区域 & 7,468 & 539 & 237 & 119 & 8,363 \\
\hline 市街化調整区域 & 2,733 & 160 & 120 & 82 & 3,095 \\
\hline 非線引き用途地域 & 872 & 40 & 43 & 45 & 1,000 \\
\hline 邜引き白地地域 & 2,182 & 67 & 79 & 201 & 2,529 \\
\hline 都市計画区域外 & 203 & 7 & 18 & 4 & 232 \\
\hline 合計 & 13,458 & 813 & 497 & 451 & 15,219 \\
\hline
\end{tabular}

資料 : 2007 年都市計画基礎調査 (富山県)

市街化区域内農地の転用面積が199ha と最も多く、その うち住宅への転用が $126 h$ となっている。一方、人口増 加率が高い非線引き白地地域でも $117 \mathrm{ha}$ の転用がみられ、 市街化区域に次ぐ面積規模の農地転用が進んでおり、そ のうち住宅への転用が41ha、商業施設を含むその他用途 への転用が55haとなっている。

さらに、2002年〜2006年の5年間における用途別新築 件数の合計值をみると（表-10）、市街化区域内での新 築件数が8, 363件と突出して多くなっている一方、市街 化調整区域や非線引き白地地域での新築件数も多く、中 
でも住宅新築件数は市街化調整区域で2, 733件、非線引 き白地地域で2, 182件となっており、依然としてスプロ 一ル化が進行しているものと考えられる。

これらの開発の背景には、地価の安さが一つの要因 となっているものと推察される。国道41号（旧富山市城 址公園前〜旧大沢野町笹津間）沿道の地価（路線価）と 都市計画区分の関係をみると（図-2）、市街化区域の平 均地価が約112,000円/ $\mathrm{m}^{2}$ であるのに対し、非線引き白地 地域では約30,000円/m²であり、調整区域（約48,000円/ $\mathrm{m}^{2}$ ）や非線引き用途地域（約 31,000 円 $/ \mathrm{m}^{2}$ ）に比べて相 対的に安い。

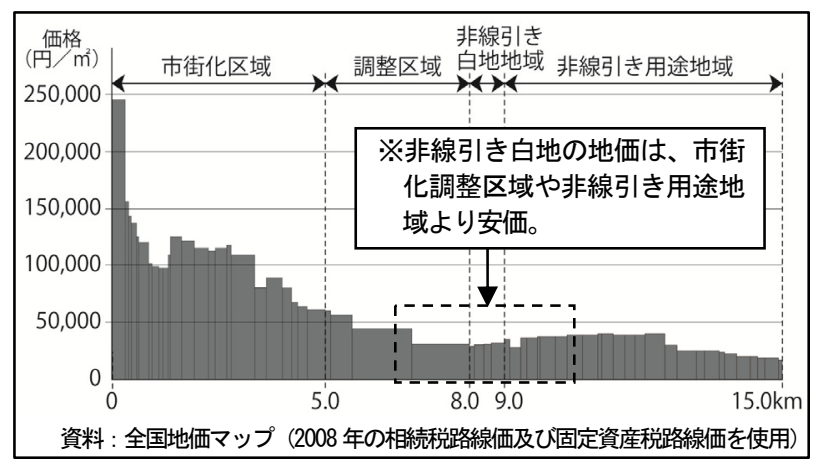

図-2 都市計画区分と地価の関係（国道 41 号）

富山県では、2005年合併前の富山市・高岡市・新湊 市・小杉町 · 大島町 ・ 下村 $\cdot$ 大門町から構成される「富 山高岡広域都市計画区域」を指定して1971年に線引きを 導入し、それ以外の都市計画区域では、当初線引きの人 口要件（10万人以上）や開発圧力の低さ等から、線引き を導入してきていない。しかし、図-1に示すように、線 引きを導入している富山高岡広域都市計画区域の枠組み と、都市間の通勤者数等から設定した実態上の都市圈 （富山都市圈）の不整合が生じているとともに、日常生 活圈として結びつきの強い旧富山市と周辺市町村の間に 土地利用規制格差が生じており、従来の市町村の枠組み を超えて市街化が進行している。特に、土地利用規制が 緩いことに加え、地価が安く自動車での交通利便性が高 い非線引き白地地域での住宅等の開発が行われている。 この傾向は、今後の人口・世帯数の減少下においても、 自動車での移動を前提とした郊外部における戸建て住宅 でのライフスタイルを志向する人々の需要がある限り継 続するものと考えられる。

一方、富山都市圈における市街地内（市街化区域や 非線引き用途地域）の土地利用現況をみると（図-3）、 市街化区域の $15 \%$ 、非線引き用途地域の $25 \%$ 「か田畑」 や「その他の空地」となっており、本来、都市的開発を 誘導す心゙き市街地内において計画的な土地利用が図られ ていない状況となっている。

以上のことから、富山都市圈では、土地利用規制格差 を背景とした地域変容が進んでおり、線引きされた中心 都市に隣接する非線引き都市の中でも、土地利用規制の

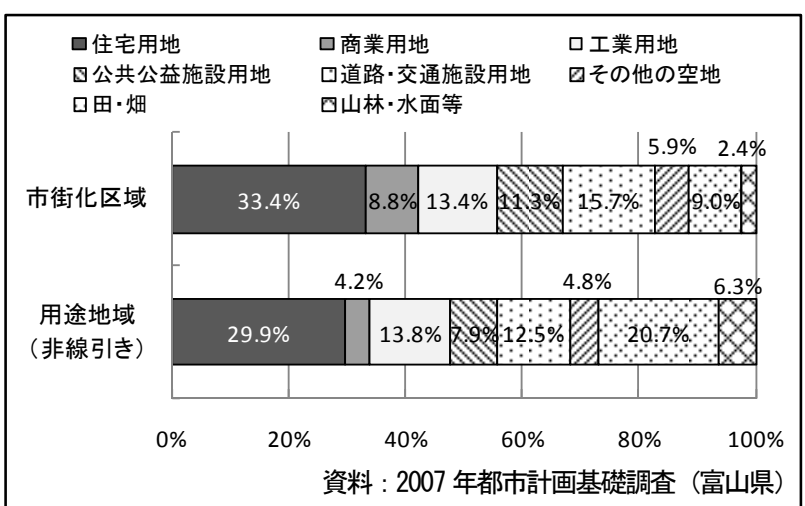

図-3 富山都市圏における市街地内の土地利用現況

緩い白地地域での住宅開発等に伴う人口増加がみられる 実態を示した。前章で示したように、全国の多くの地方 都市圈が富山都市圈に類似した土地利用ゾーニングとな っていることから、同様の地域変容が進んできているも のと推察される。

富山都市圈の中核を成す富山市では、都市マスター プラン（平成20年3月）の中で、公共交通を軸としたコ ンパクトな都市づくりへの転換を図っていくことが提示 されている。バス停や鉄軌道駅周辺での市街地開発や都 市的土地利用を促進していくためには、一方で公共交通 沿線地域での土地利用等の誘導を図りつつ、もう一方で は都市圏レベルでの土地利用計画を機能させることが重 要である。特に、これまでの市街地拡散の受け典となっ てきた非線引き白地や都市計画区域外などの緩規制地域 での土地利用コントロールを強化していく必要がある。

\section{（2）富山高岡広域都市計画区域と周辺市町村の土地利 用規制格差と地域変容}

富山都市圈を含む広域的な地域変容を捉えるため、 線引きされた富山高岡広域都市計画区域と、非線引きの 周辺市町村 (隣接都市) の人口変動について考察する。

富山高岡広域都市計画区域の内外における人口変動 をみると（表-11）、まず富山高岡広域の内側では、旧 富山市のベッドタウン的な発展を遂げている旧婦中町で 市街化区域・調整区域ともに人口増加傾向にあり、市街 地に隣接する都市計画区域外でも一定の人口増がみられ る。一方、旧富山市や射水市では、市街化区域・調整区 域ともに人口の伸びが停滞しており、高岡市では市街化 区域・調整区域ともに減少傾向となっている。

他方、富山高岡広域に隣接する各市町村（すべて非 線引き都市）の人口変動をみると、1985年〜2005年の 20 年間における用途地域内の人口増加率が1. 100であるの に対し、白地地域では1. 301 と高く、用途地域の 2 倍以 上の人口を抱えている。隣接市町村の人口変動を個別に みると、1988年に富山高岡広域の線引きを廃止した舟橋 村では、20年間で約1.9倍に増加しているほか、滑川市 や上市町、旧大山町、旧大沢野町、旧八尾町では用途 
表-11 富山高岡広域都市計画区域内外の人口変動

\begin{tabular}{|c|c|c|c|c|c|c|c|c|c|c|c|c|c|}
\hline & \multicolumn{2}{|c|}{ 旧富山市 } & \multicolumn{3}{|c|}{ 旧婦中町 } & \multicolumn{3}{|c|}{ 射水市 } & \multicolumn{2}{|c|}{ 旧高岡市 } & \multicolumn{3}{|c|}{ 富山高岡広域 合計 } \\
\hline & $\begin{array}{c}\text { 市街化 } \\
\text { 区域 }\end{array}$ & $\begin{array}{l}\text { 調整 } \\
\text { 区域 }\end{array}$ & $\begin{array}{c}\text { 市街化 } \\
\text { 区域 }\end{array}$ & $\begin{array}{l}\text { 調整 } \\
\text { 区域 }\end{array}$ & $\begin{array}{c}\text { 都計 } \\
\text { 区域外 }\end{array}$ & $\begin{array}{c}\text { 市街化 } \\
\text { 区域 }\end{array}$ & $\begin{array}{l}\text { 調整 } \\
\text { 区域 }\end{array}$ & 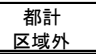 & $\begin{array}{c}\text { 市街化 } \\
\text { 区域 }\end{array}$ & $\begin{array}{l}\text { 調整 } \\
\text { 区域 }\end{array}$ & $\begin{array}{c}\text { 市街化 } \\
\text { 区域 }\end{array}$ & $\begin{array}{l}\text { 調整 } \\
\text { 区域 }\end{array}$ & 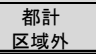 \\
\hline \multirow{2}{*}{ 1985年 } & 239,550 & 74,561 & 10,137 & (6,650 & 111,165 & 64,154 & $\begin{array}{l}28,863 \\
\end{array}$ & 725 & $\begin{array}{l}128,728 \\
\end{array}$ & (47,052 & 4442,569 & 157.126 & 111,890 \\
\hline & 1.000 & 1.000 & 1.000 & 1.000 & 1.000 & 1.000 & 1.000 & 1.000 & 1.000 & 1.000 & 1.000 & 1.000 & 1.000 \\
\hline \multirow{2}{*}{ 1990年 } & 249,887 & 71,367 & 10,746 & 6,567 & $.11,354$ & 63,120 & 28,631 & 1,161 & 126,882 & 48.584 & 450,635 & 155,149 & 12.515 \\
\hline & 1.043 & 0.957 & 1.060 & 0.988 & 1.017 & 0.984 & 0.992 & 1.601 & 0.986 & 1.033 & 1.018 & 0.987 & 1.053 \\
\hline \multirow{2}{*}{ 1995年 } & 254,093 & 71.282 & 13.720 & 7.127 & 11.732 & 63,205 & 29,057 & 719 & 128.015 & 45.592 & 459,033 & 153,058 & 12.451 \\
\hline & 1.061 & 0.956 & 1.353 & 1.072 & 1.051 & 0.985 & 1.007 & 0.992 & 0.994 & 0.969 & 1.037 & 0.974 & 1.047 \\
\hline \multirow{2}{*}{ 2000年 } & 255,629 & 70.071 & 14,935 & 7,650 & 111,943 & 65,045 & 27,780 & 678 & 129,302 & 42,882 & 464,911 & 148,383 & 12,621 \\
\hline & 1.067 & 0.940 & 1.473 & 1.150 & 1.070 & 1.014 & 0.962 & 0.935 & 1.004 & 0.911 & 1.050 & 0.944 & 1.061 \\
\hline \multirow{4}{*}{ 2005年 } & 250,442 & 74,905 & 16,181 & 8,332 & 111,935 & 64,658 & 28,900 & 651 & 125,858 & 41,827 & 457,139 & 153,964 & 12.586 \\
\hline & 1.045 & 1.005 & 1.596 & 1.253 & 1.069 & 1.008 & 1.001 & 0.898 & 0.978 & 0.889 & 1.033 & 0.980 & 1.059 \\
\hline & \multicolumn{3}{|c|}{ 滑川市 } & \multicolumn{3}{|c|}{ 上市町 } & 舟橋村 & \multicolumn{3}{|c|}{ 立山町 } & \multicolumn{3}{|c|}{ 旧大山町 } \\
\hline & 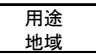 & $\begin{array}{l}\text { 白地 } \\
\text { 地域 }\end{array}$ & $\begin{array}{c}\text { 都計 } \\
\text { 区域外 }\end{array}$ & 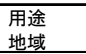 & $\begin{array}{l}\text { 白地 } \\
\text { 地域 }\end{array}$ & $\begin{array}{c}\text { 都計 } \\
\text { 区域外 }\end{array}$ & $\begin{array}{l}\text { 白地 } \\
\text { 地域 }\end{array}$ & $\begin{array}{l}\text { 用途 } \\
\text { 地域 }\end{array}$ & $\begin{array}{l}\text { 白地 } \\
\text { 地域 }\end{array}$ & 都計区域外 & $\begin{array}{l}\text { 用途 } \\
\text { 地域 }\end{array}$ & $\begin{array}{l}\text { 白地 } \\
\text { 地域 }\end{array}$ & $\begin{array}{c}\text { 都計 } \\
\text { 区域外 }\end{array}$ \\
\hline \multirow{2}{*}{ 1985年 } & 16,027 & 14,577 & 276 & 8,969 & 14,456 & 675 & 1,419 & 5,572 & 19,610 & 2,792 & 44,364 & 6,926 & 2,806 \\
\hline & 1.000 & 1.000 & 1.000 & 1.000 & 1.000 & 1.000 & 1.000 & 1.000 & 1.000 & 1.000 & 1.000 & 1.000 & 1.000 \\
\hline \multirow{2}{*}{ 1990年 } & 16.495 & 14,243 & 185 & 8,771 & .14 .403 & 497 & 1,371 & 5,463 & 19,458 & 2,316 & 4.283 & 6,781 & 2,506 \\
\hline & 1.029 & 0.977 & 0.670 & 0.978 & 0.996 & 0.736 & 0.966 & 0.980 & 0.992 & 0.830 & 0.981 & 0.979 & 0.893 \\
\hline \multirow{2}{*}{ 1995年 } & 13,728 & 17,883 & 230 & 9,527 & 13,653 & 497 & 1,658 & 5,205 & 20,464 & 1,775 & 3,699 & 7,448 & 1,892 \\
\hline & 0.857 & 1.227 & 0.833 & 1.062 & 0.944 & 0.736 & 1.168 & 0.934 & 1.044 & 0.636 & 0.848 & 1.075 & 0.674 \\
\hline \multirow{2}{*}{ 2000年 } & 13,696 & 19.478 & 189 & 7.829 & 15.393 & 140 & 2.153 & 5.246 & 20,677 & 2.071 & 3,526 & 8.126 & 1.681 \\
\hline & 0.855 & 1.336 & 0.685 & 0.873 & 1.065 & 0.207 & 1.517 & 0.941 & 1.054 & 0.742 & 0.808 & 1.173 & 0.599 \\
\hline \multirow{4}{*}{ 2005年 } & 13.470 & 20.341 & 191 & 7.468 & 15.472 & 99 & 2.673 & 5,905 & 20,347 & 1,759 & 3.384 & 7.971 & 1,362 \\
\hline & 0.840 & 1.395 & 0.692 & 0.833 & 1.070 & 0.147 & 1.884 & 1.060 & 1.038 & 0.630 & 0.775 & 1.151 & 0.485 \\
\hline & \multicolumn{2}{|c|}{ 旧大沢野町 } & \multicolumn{3}{|c|}{ 旧八尾町 } & \multicolumn{2}{|c|}{ 旧砺波市 } & \multicolumn{3}{|c|}{ 旧福岡町 } & \multicolumn{3}{|c|}{ 隣接市町村 合計 } \\
\hline & $\begin{array}{l}\text { 用途 } \\
\text { 地域 }\end{array}$ & $\begin{array}{l}\text { 白地 } \\
\text { 地域 }\end{array}$ & $\begin{array}{l}\text { 用途 } \\
\text { 地域 }\end{array}$ & $\begin{array}{l}\text { 白地 } \\
\text { 地域 }\end{array}$ & $\begin{array}{c}\text { 都計 } \\
\text { 区域外 }\end{array}$ & $\begin{array}{l}\text { 用途 } \\
\text { 地域 }\end{array}$ & $\begin{array}{l}\text { 白地 } \\
\text { 地域 }\end{array}$ & $\begin{array}{l}\text { 用途 } \\
\text { t地域 }\end{array}$ & $\begin{array}{l}\text { 白地 } \\
\text { 地域 }\end{array}$ & 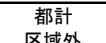 & $\begin{array}{l}\text { 用途 } \\
\text { t地域 }\end{array}$ & 白地 & $\begin{array}{l}\text { 都計 } \\
\text { 区㳦外 }\end{array}$ \\
\hline 1985年 & 9,808 & 10,372 & & & & 6,664 & 29,852 & 4,172 & 7,322 & 732 & 55,576 & 104,534 & 7,281 \\
\hline 1985年 & 1.000 & 1.000 & & & & 1.000 & 1.000 & 1.000 & 1.000 & 1.000 & 1.000 & 1.000 & 1.000 \\
\hline 1990 年 & 10,007 & 10,798 & & & & 6.676 & 30,394 & 4,400 & 7.557 & 446 & 56.095 & 105.005 & 5,950 \\
\hline 1990年 & 1.020 & 1.041 & & & & 1.002 & 1.018 & 1.055 & 1.032 & 0.609 & 1.009 & 1.005 & 0.817 \\
\hline 1995年 & 8.146 & 13,670 & 9,743 & 12,570 & 3,799 & 7.049 & 31,482 & 4,689 & 8,054 & 477 & 61,786 & 126,882 & 8,670 \\
\hline 1995年 & 0.831 & 1.318 & 1.000 & 1.000 & 1.000 & 1.058 & 1.055 & 1.124 & 1.100 & 0.652 & 1.112 & 1.214 & 1.191 \\
\hline 2000年 & 9,004 & $\begin{array}{r}13,638 \\
\end{array}$ & 9,351 & 12,972 & 3,603 & 7,783 & 32,961 & 4,788 & 8,223 & 487 & 61,223 & 133,621 & 8.171 \\
\hline 2000 年 & 0.918 & 1.315 & 0.960 & 1.032 & 0.948 & 1.168 & 1.104 & 1.148 & 1.123 & 0.665 & 1.102 & 1.278 & 1.122 \\
\hline 2005年 & 9,242 & 13,389 & 8.882 & 12,929 & 3,217 & 8,358 & 34.170 & 4,433 & 8,685 & 426 & 61,142 & 135,977 & 7.054 \\
\hline 2005年 & 0.942 & 1.291 & 0.912 & 1.029 & 0.847 & 1.254 & 1.145 & 1.063 & 1.186 & 0.582 & 1.100 & 1.301 & 0.969 \\
\hline
\end{tabular}

地域内の人口が減少し、白地地域の人口が増加している。 また、市街地内外で人口減少が進んでいる旧高岡市に隣 接する旧砺波市や旧福岡町の非線引き白地では、人口増 加傾向となっており、土地利用規制格差を背景に、都市 計画の目指すべき方向と実際の人口集積が乘離している 状況がうかがえる。

\section{6. 地方都市圏における土地利用ゾーニングの方向}

前章までの分析から、地方都市圈では、中心都市の 人口割合が非常に高いものの、隣接あるいは連接する周 辺都市の非線引き白地地域での人口増加率が高くなって おり、土地利用規制格差を背景とした都市圈レベルでの 市街地の拡散が全国の地方圈で共通的に進しでいる実態 が明らかとなった。また、その典型的な事例として取り 上げた富山都市圈の分析から、市街化区域内や非線引き 用途地域内の低末利用地を残したまま、規制が緩く地価 の安い非線引き白地地域での開発が進み、結果として人 口の流出につながっていることを明らかにした。

今後、人口減少・低成長時代に見合った都市づくり 及び自然環境の保全等を進めていくためには、市町村個 別の都市計画的対応にとどまらず、実態的な都市圈を設 定し、広域的な枠組みでの土地利用コントロールを機能 させていく必要がある。例えば、都市圈の中で「開発す べきところ」、「場合によって開発を認めるところ」、

「開発を抑制すべきところ」といった土地利用区分を設 定し、それを実現していくための法的担保を有する土地 利用制度が求められる。

現行の法制度下においては、このような課題への都
市計画的対応として、特定用途制限地域の活用などが図 られている。しかし、特定用途制限地域では住宅系用途 をきめ細かく規制誘導することが困難であることや、用 途地域に類似した最低限の規制として活用されているこ とが多いこと、また、市町村決定の都市計画であること から、広域的な観点で戦略的に土地利用コントロールを 図るツールとしては不十分であると考えられる。

人口減少や超高齢社会への対応を迫られる中、集約 型都市構造への転換を都市マスタープラン等に位置づけ る自治体が増加している。しかし、これらの市町村独自 の取り組みに対して、都市圈レベルの広域的な観点から その実現を支援する仕組みや制度が不十分である。これ らの課題を踏まえつつ、地方都市圈では、土地利用規制 格差是正に向けて既存の都市計画制度を活用するだけで はなく、都市圈を構成する市町村が各々の目指寸コンパ クトな都市づくりを円滑に進められるよう、広域的な土 地利用のビジョンの共有やゾーニング制度による実現を 図っていく必要がある。また、土地利用ゾーニングにあ たっては、線引きあるいは非線引きで一律に規制するの ではなく、市街化区域や調整区域、非線引き白地地域の 中でも、選択と集中を図り、例えば鉄軌道駅周辺の都市 的開発については積極的な誘導を図りつつ、それ以外の 地域では規制強化できるようなゾーニング制度の運用が 必要と考えられる。

\section{7. まとめ· 今後の課題}

本論文では、都市雇用圈の考え方を踏襲して設定し た全国の地方都市圈を対象に、土地利用規制格差と人口 
変動等の地域変容について分析・考察した。

全国の地方都市圈を対象とした分析では、まず、都 市圏における線引きの設定状況をタイプ分類すると、

「中心都市 : 線引き十周辺都市 : 非線引き」のタイプが 多く、線引き設定当初に開発圧力の高い都市のみを線引 き対象としたものと考えられる都市圈が多いことが明ら かとなった。これらの都市圈における人口変動について みると、中心都市の人口増加に加えて、中心都市に隣接 あるいは連接する都市の非線引き都市計画区域における 人口増加率が相対的に高く、土地利用規制の緩い地域で の人口増加傾向が全国の地方都市圈に共通してみられる ことを示した。

また、「中心都市 : 線引き十周辺都市 : 非線引き」 の典型例である富山都市圏の事例分析では、非線引き都 市の中でも規制の緩い白地地域での住宅開発やそれに伴 う人口増加が進んでおり、広域都市計画区域の枠組みと 実態上の都市圈の乘離を背景に、当初は都市的土地利用 を想定していなかった非線引き白地地域でのスプロール 的な農地転用や新築行為が行われている実態を明らかに した。さらに、富山高岡広域都市計画区域の内外におけ る人口変動の分析から、都市計画の目指す心゙き方向と実 際の人口集積に乘離が生じていることを示した。以上の 分析結果を踏まえつつ、地方都市圈における今後の土地 利用ゾーニングの方向について考察・提言した。

昨今、市町村の都市計画に対する都道府県の同意要 件の廃止が検討されるなど、都市計画行政に関する地方 分権が進んでいる。しかし、市街地の無秩序な拡散への 対応は、自治体単独では難しい状況であり、広域的な観 点からの都市計画の重要性が高まっている。今後、人口 減少が進むとしても、規制が緩く地価が安い郊外部での 開発需要は続くものと考えられ、既成市街地や農山漁村 の空洞化と相まって、より一層スプロール化が進行する ことが想定される。このような事態を未然に防止し、都 市部の活力と農山漁村の魅力が発揮される集約型都市構 造を実現していくためには、広域的な土地利用ゾーニン グの仕組みや、それを支える法制度の充実が望まれる。
【補注】

（1） 国土交通省土地・水資源局土地情報課による「土地所有・利用の 概況」で定義された三大都市圈（東京都、神奈川県、千葉県、埼 玉県、愛知県、三重県、大阪府、京都府、兵庫県）を除く道県。

（2）本研究では、金本・徳岡の都市圈設定基淮の考え方を踏まえ、地 方圈における2000年時点の県庁所在都市及び中核市（計42市）を 中心都市とし、これらの都市への通勤率が $10 \%$ 以上の市町村を抽 出して都市圈を設定した。なお、通勤率は、自市町村から他市町 村への通勤者数 $\div$ 自市町村全体の通勤者数で算出した。

（3）富山県では、2007年に県内のすべての都市計画区域を対象として 都市計画基礎調査を実施している。

\section{【参考文献】}

1）松川寿也・岩本陽介・中出文平 (2007) : 線引き都市計画区域外 縁部での土地利用規制格差とその是正手法の可能性と課題 - 松本 都市計画区域とその周辺を対象として - 、都市計画論文集、 No. 42-3、pp. 793-798.

2）岩本陽介・松川寿也・中出文平（2007）：特定用途制限地域の指 定実態と活用可能性に関寸る研究 - 岐阜県美濃加茂市と富加町の 事例を通じて - 、都市計画論文集、No. 42-3、pp. 799-804.

3）藤井さやか・小山雄資・大澤義明（2009）：全国の指定実態分析 からみた特定用途制限地域の類型化に関寸る研究、都市計画論文 集、No. 44-3、pp. 265-270.

4）木谷弘司・川上光彦（1998）：市街化調整区域における土地利用 コントロール方針に関する調查研究 - 地方中心都市を事例として 一、都市計画論文集、No. 33、pp. 511-516.

5）国立社会保障・人口問題研究所（2007）：日本の都道府県別将来 推計人口（平成19年5月推計）

6) 内田一平・中出文平 (1997) : 県庁所在地方都市圈における市街 地拡大の実態と要因に関する研究、都市計画論文集、NNo. 32、 pp. $415-420$.

7）石村壽浩・鵤心治・中出文平・小林剛士（2006）：香川県線引き 廃止に伴う土地利用動向に関する研究、日本建築学会計画系論文 集、No. 607、pp. 103-110.

8）坂内陽子・姥浦道生・赤浐弘平・和多治（2008）：東予広域都市 計画区域における線引き廃止前後の開発動向の変化に関する研究 都市計画論文集、No. 43-1、pp. 28-33.

9）前迫信也・小林大毅・吉武哲信・出口近士（2002） : 都城市の都 市計画区域内における線引き廃止後の開発動向に関する考察、都 市計画論文集、No. 37、pp. 697-702.

10）鈴木潔・内海麻利（2008）：市町村合併の土地利用規制一の影響 とその対応に関する研究、都市計画論文集、No. 43-3、pp. 301306.

11）山口邦雄（2008）：市町村合併を契機とした都市構造の再構築と 都市計画区域の見直しに関する研究、都市計画論文集、No. 43-3、 pp. 931-936.

12）橋本隆・湯沢昭（2007）：市町村合併後の都市計画区域の地域格 差と財政負担に関寸る研究、都市計画論文集、No. 42-3、pp. 865870.

13）金本良嗣・徳岡一幸（2002）：日本の都市圈設定基淮、応用地域 学研究、No. 7、pp. 1-15.

\section{地方都市圏における土地利用の規制格差と地域変容 一全国的な人口変動の動向と富山都市圏の事例分析一*}

片岸 将広**・川上 光彦***・小柳 玩利 $* * * *$ ・埒 正浩*****

本研究では、地方都市圏を対象とした人口変動等の分析から、これまでの都市計画制度下において、都市 圏レベルで市街地の拡散が進行し、当初は都市的開発を想定していなかった非線引き都市の人口増加率が高 くなっていることを示した。また、富山都市圈の事例分析を通じて、線引きが設定された中心都市に隣接あ るいは連接する非線引き白地地域において開発が進み、一方の市街化区域や用途地域内では低未利用地が多 く残存している実態等を明らかにした。さらに、上記の分析結果を踏まえ、地方都市圈の土地利用ゾーニン グのあり方について考察した。 
Land Use Control Gaps between Municipalities of Local Conurbation Area and Regional Transformation -Trend of population change of Local Conurbation Area and Case Study of Toyama Conurbation Area-* By Masahiro KATAGISHI** - Mitsuhiko KAWAKAMI*** · Takuto OYANAGI**** • Masahiro RACHI*****

This paper shows that the population increased in non-dividing zoning urban planning area before where urban development was not assumed, by analyzing the population change of local conurbation area. Then we clarified that the non-dividing zoning urban planning area shows increase of population, in contrast unused land of the central city increases, where dividing zoning is introduced, by case study of Toyama conurbation area. In addition, it proposed the ideal way of the land use zoning of local conurbation area. 